\title{
ERRATA 2
}

O Conselho Editorial da Revista Psicologia em Estudo comunica que o v. 12, n. 3, set./dez. 2007, publicou o seguinte erro de impressão retificado a seguir:

\section{Na página 502}

Onde se lê:

- $\quad$ Aceito em 11/007/2006

Leia-se:

- $\quad$ Aceito em 11/07/2007 